\title{
A CO-OPERATIVE PROGRAMME TO EXTEND IAMB PRODUCTION IN SOUTHLAND
}

D.R. Stevens', D.M. Lee ${ }^{2}$, M.B. Dillon ${ }^{3}$ and J.D. Turner' 'Grasslands Division, DSIR, Gore

${ }^{2}$ Challenge Meats Ltd, Mataura

${ }^{3}$ Nine Mile Road, Gore

Abstract

In Southland lambs are processed from November to May, resulting in inefficient use of processing facilities and an inability to meet some market requirements for a continuous supply of product However, spreading of lamb slaughter is hindered by the seasonal pattem of pasture growth and climatic conditions in Southland.

Grasslands DivisionDSIR, Mervyn Dillon and Challenge Meats Ltd are now cc-operating in a programme to overcome the pasture growth and climatic constraints to extend the period of lamb slaughter in Southland.

In the first part of the study silage alone or 1 various combinations with gram was fed to lambs in winter, Silage-fed lambs with a high proportion of grain grew at the best and most consistent rates. Silage-fed lambs without grain supplements had inconsistent weight gains and a growth response so variable that treatments ended early. Weight gains for grass-fed lambs were affected by preconditioning on to silage and reduction in the feed supply during winter. However, pasture-fed lambs still produced the heaviest carc asses and greatest retums. Carcass grades had to be monitored closely to achieve maximum retums.

Keywords: Southland, out-of-season lamb. lamb production, winter feeding

\section{BACKGROUND}

Pasture growth in Southland (46" 07' South) peaks in spring and summer with a severe winter deficit. This has been overcome in the past by conserving feed in-situ in the autumn and rationing it through the winter (Harris 8 Hickey 1978). To enable a sufficient build-up of feed in the autumn, lambs must be sold during summer, as only enough feed for the ewes and replacements can be accumulated for wintering without supplements.

However, changing demand for sheep meat and the requirement for improved processing efficiency have created a greater need for year-round slaughter of lambs. Pasture can be used for finishing large numbers of lambs in winter but only with a major reduction in ewe numbers and a consequent reduction in annual lamb production. This means other options must be explored to enable more lambs to be held through into the winter and following spring to provide an improved lamb supply. Options available are specialist winter feedcrops, of which 'Grasslands Moata' Italian ryegrass is the best quality, and hay, grain and silage. Additional feed costs must be kept low to maintain economic returns.

In 1986 Grasslands Division, Gore, began a programme to look at the potential for slaughtering lambs $\mathbf{1 2}$ months of the year in Southland. Research was initiated into all facets of feed supply and demand to fit a new animal production pattern. Realising the potential of year-round slaughter to the meat industry, Grasslands Division approached Challenge Meats Ltd, for assistance with funding, and Mervyn Dillon, a farmer who was looking for ways to feed lambs during winter.

The results of a study of Moata Italian ryegrass to grow lambs through the winter was presented elsewhere in this Proceedings (Hickey \& Baxter 1989). 


\section{THE CO-OPERATIVE APPROACH}

Co-operation between processors, researchers and farmers offers the opportunity to blend skills from each group and maximise the value of research. The farmer can supply stock, land and day-to-day management. The processor can provide slaughtering facilities, carcass data and tenderness measurements. As a consequence processors can ensure technology is available in their region to provide the appropriate raw product when required.

\section{EXTENDING THE GROWING PERIOD THROUGH CONSERVED FEED}

Silage was assessed as the best conservation option. It can be easily made during spring and summer and high quality silage is sufficient for finishing lambs (Fitzgerald 1986). Making silage can also improve production and white clover content of pasture (Wolton et al. 1970). Because any form of conservation has associated costs and quality losses (Barry ef al, 1980), grain supplements available in Southland were considered.

Silage can be fed to ewes or lambs. However, to overwinter large numbers of lambs some silage must be fed to them, as pasture build-up in autumn is not enough to allow for growth rations in the winter.

Feeding silage on pasture severely damages soil and causes waste because of the wet soil conditions in Southland winters. Therefore, feedlots may be necessary, with silage fed as a sole diet without grass supplementation.

Therefore, it is important to monitor the growth rates of lambs on silage with and without grain supplements, to ensure that carcass weights of $16-20 \mathrm{~kg}$ can be achieved throughout winter.

\section{METHODS}

The experiment was set up on the Dillon property at Balfour. Treatments were pasture as control, silage fed outdoors on a feedlot and four indoor feeding options (daily per head) all using silage: silage alone, silage plus 250-370 g oats, silage plus $250 \mathrm{~g}$ barley and silage plus $500 \mathrm{~g}$ barley. All grain supplements were crushed before being added to the diet. The pasture group was fed under the farmers normal management, set stocked at $600-800 \mathrm{~kg}$ DM/ha on offer.

Spring-born Romney ram lambs were introduced to silage over a period of 10 days beginning on 31 March with 250 lambs. Twenty-two lambs failed to adapt to silage and were rejected. The lambs were weighed regularly from the start of the trial on 13 April until slaughter after 15 weeks on 21 July. Weight gains were monitored and lambs not performing on any treatment over a 6-week period were removed.

Lambs were vaccinated for clostridial diseases and salmonella. Terromycin powder was applied to their eyes to prevent infection and they were walked through a solution of formalin (40:1) to prevent foot infections. Lambs were drenched with selenium added Systamex ${ }^{\oplus}$ before the trial. Half the lambs in each treatment were drenched on 15 May with Hydravit ${ }^{\oplus}$ (2.5 ml 100000 i.u./g Vitamin A, 20000 i.u./g Vitamin $D_{3}$ and $40 \mathrm{mg} / \mathrm{g}$ Vitamin $\left.E\right)$ and selenium $(1.5 \mathrm{ml})$ to test for possible vitamin deficiencies.

Silage was fed daily allowing for $10 \%$ refusal. Grain was weighed at the start of the trial and then fed out by volume. Feed intakes were assessed over 2 days in both weeks 7 and 14 by weighing the offered and rejected silage and grain daily. Clean water was supplied continuously. 


\section{Feed quality and intake}

\section{RESULTS}

The quality of the silage averaged $65 \%$ digestibility, indicating a reasonable maturity of the pasture. Protein content was $20.5 \%$ with adequate nutrient levels. Dry matter (DM) content averaged $25.3 \%$ and palatability was good. The grass diet was predominantly ryegrass-white clover.

Silage intake (Table 1) was highest for the lambs fed outdoors, agreeing with other results showing that voluntary feed intake increases as rain and colder temperatures increase maintenance requirement for lambs outdoors (ARC. 1965; Kennedy 1983). For the indoor treatments, adding grain increased total intake, and therefore did not replace silage on a 1 for 1 basis. This is normal with wilted silage (Fitzgerald 1986) and may be due to a better carbohydrate supply enhancing digestion and microbial protein synthesis (Gill \& Ulyatt 1977).

Table 1: Average feed intake levels for silage treatments over 4 days (kg/head/day)

\begin{tabular}{lccccc}
\hline \multicolumn{5}{c}{ Silage } & treatments \\
& Outdoors & Indoors & oats & Barley & Barley \\
& & & $250-370 \mathrm{~g}$ & $250 \mathrm{~g}$ & $500 \mathrm{~g}$ \\
\hline Silage & 1.22 & 1.06 & 097 & 1.02 & 0.65 \\
Gram & - & - & $0.21(0.31)$ & 0.20 & 0.40 \\
\hline
\end{tabular}

The source of oats was changed during week 8 . The oats were not reweighed until the assessment of feed intakes in week 14 and consequently the oat diet had increased to $370 \mathrm{~g} / \mathrm{head} /$ day because of a much higher bushel weight of the new oats.

\section{Lamb growth - adjustment period}

Lambs in all treatment groups were put in a paddock with a grass ration of approximately $50 \%$ of their diet, with free access to silage. After 3 days they had eaten no silage as they had too much space and were unfamiliar with the feed. They were then confined to a bare paddock and allowed access to grass for 1 hour each day. However, this only led to many animals waiting at the gate to be let out. For the last 4 days they were fed silage as a sole diet. The lack of an increase in silage intake and a decrease in grass resulted in lambs losing an average of $1.8 \mathrm{~kg} / \mathrm{head}$ liveweight during the 1 O-day introductory period.

\section{Lamb growth rates}

In the 3 weeks after conditioning lambs on all treatments averaged a good weight gain (Fig. 1). However, growth slowed for the next 3 weeks. Problems may have been caused by lambs standing in troughs and fouling feed during this period. Apart from rejection of feed this can lead to high urea intakes and excess ammonia building up in the rumen (MAFF 1978).

Lamb growth rates were more consistent for the remainder of the trial after rails were added to the troughs to prevent fouling. Of the silage treatments, lambs with the addition of $500 \mathrm{~g}$ barley grew at the best rate throughout the trial.

Growth rates were variable with silage as the sole diet and some lambs consistently lost weight during the trial. Because of this the indoor treatment was concluded at week 10 and the outdoor treatment at week 13 (Fig. 1). Intake of silage was low because of low digestibility.

Oats at 250-370 $\mathrm{g} / \mathrm{head}$ and barley at $250 \mathrm{~g} / \mathrm{head}$ resulted in similar liveweight gains, demonstrating the superiority of barley for growth because of its higher feed value (12.5 MJ/ME/kg) than oats (1 1.5 MJ/ME/kg) (Ulyatt et al. 1980).

Lamb growth rates on pasture declined initially because they were conditioned 


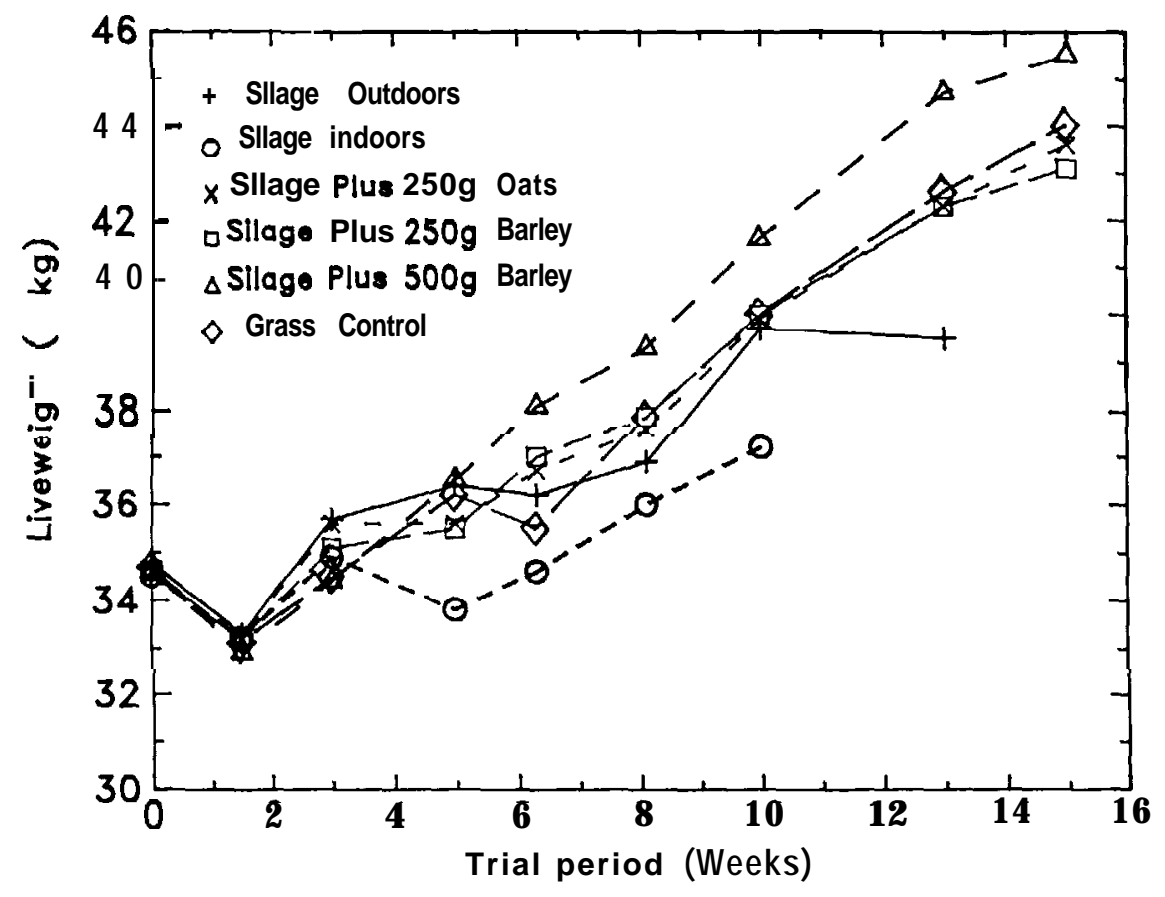

Figure 1. Lamb liveweight changes during the trial.

to silage along with the other groups, and because of decline in pasture availability (Hughes 1983). Had they not been conditioned to silage they would have been at least $1.8 \mathrm{~kg}$ heavier at the end of the trial, and would also have performed better if they had access to more pasture. This is one of the problems of set stocking lambs in winter without adjusting ewe numbers. Rotational grazing with good allocation of feed supply will result in better lamb growth in winter (Hickey 8 Baxter 1989) than in this trial, but the requirements of large numbers of lambs still cannot be met without silage supplementation. Vitamin supplementation did not affect weight gain: both groups of lambs gained $6.1 \mathrm{~kg}$ liveweight over the 8-week period after treatment. Carcass data (Table 2)

Carcass data for the two silage-only treatments has been estimated because they ended early. Silage outdoors had the lowest liveweights and carcass weights, and pasture-fed lambs the highest. The dressing-out percentage was also much higher on the grass control whereas all others were similar. Usually grain increases

Table 2 Carcass weights, dressmg-out $\%$ and grades

\begin{tabular}{|c|c|c|c|c|c|c|}
\hline & & & Silage & treatments & & \\
\hline & Outdoors' & Indoors' & $\begin{array}{c}\text { Oats } \\
250 \cdot 370 \mathrm{~g}\end{array}$ & $\begin{array}{l}\text { Barley } \\
250 \mathrm{~g}\end{array}$ & $\begin{array}{l}\text { Barley } \\
500 \mathrm{~g}\end{array}$ & $\begin{array}{l}\text { Pasture } \\
\text { control }\end{array}$ \\
\hline Carcass wt (kg) & 17.0 & 149 & 18.8 & 17.9 & 18.9 & 19.7 \\
\hline Dressing-out (\%) & 42.7 & 425 & 43.8 & 41.9 & 41.9 & 45.5 \\
\hline Grades $Y$ and $P(\%)$ & 92.1 & 100 & 81.6 & 62.9 & 59.5 & 82.8 \\
\hline$T$ and $F(\%)$ & 7.9 & 0 & a. a & 17.1 & 40.5 & 17.2 \\
\hline
\end{tabular}

1 Carcass weights and grades were estimated from liveweight and field assessment. Dressing-out Percentage was from a sample. 
dressing-out but the silage-fed lambs may have had a greater gut fill, because of the lower digestibility of the silage (Ulyatt et al. 1980).

The carcass grades show the effects of the large amounts of grain in the diet. The $500 \mathrm{~g}$ barley, a high energy diet, had an unacceptably high percentage of lambs in the $\mathrm{T}$ (Trimmer) and $\mathrm{F}$ (Fat) grades. High protein supplements and better quality silage may be more appropriate for growing lean heavy lambs, as fat deposition is lessened (Orskov et al. 1976).

\section{CONCLUSIONS}

Grass feeding of lambs was the best option when the preconditioning losses were added back on. However, grass must be of good quality and length to grow lambs effectively, and rotational grazing will best allocate the appropriate feed to ensure good weight gains.

Grain was required in all silage treatments to ensure weight gains, though silage quality is still important. Making silage from short leafy pasture, although more expensive per unit of DM may be more effective and could reduce grain inputs.

The conditioning period is of utmost importance. Close monitoring is required and pasture intakes must be reduced at a constant rate throughout while silage intake is increasing. This will ensure a consistent weight gain rather than a loss, making silage/grain diets similar to pasture for lamb growth. Removal of lambs which do not adapt is important to ensure good economic returns.

The success of the grain diets indicated that growth problems were energy related to content and intake by lambs rather than to vitamins or minerals. However, the high percentage of $\mathrm{T}$ and $\mathrm{F}$ grade lambs with these diets indicates that high protein supplements may need to be considered for heavy lean lamb production.

Strategic use of grain may be an effective way to bring lambs to final weight and condition.

\section{BENEFITS OF A CO-OPERATIVE RESEARCH PROGRAMME}

The farmer benefits from the research results by achieving his aims faster. Farm-scale research programmes with appropriate financial and management constraints enable him to accept research results more readily. The researchers also pass on other pasture management techniques which benefit the farmer, who learns first-hand new management and pasture modifications. New ideas can then spread into the whole farming community.

By monitoring lamb carcasses the farmer has a good insight into the type of lamb required. Close contact with the processors also enables the farmer to appreciate their problems and the work being done to rectify them.

If programmes prove successful, the processor will gain from improved plant efficiency, and continuity of supply.

\section{DISADVANTAGES}

A farmers workload and sometimes his capital outlay can increase, although this can usually be incorporated into the farming system.

The processor carries most of the risk, and the cost, particularly during early market development. Factors such as the exchange rate, local or international competition, or foreign regulations mean no assurance of economic viability. 
Acknowledgements

The authors wish to acknowledge Gray Dillon, Neil Hanning. Trevor Johnston and Staff at the Makarewa Freezing Works, Norman Lake, Gordon Baxter and Marie Casey for their contributions in making these trials a success.

\section{References}

AR.C. 1965. The nutrient requirements of farm livestock, No. 2, Ruminants. London, Agricultural Research Council

Barry. T.N., Marsh, R.; Reardon, T.F.; South, A 1980. In Supplementary feeding. NZ Society of Animal Production Occasional Publication 7

Coop. I.E.; Clark. B.R. 1955. NZ journal of science and technology A37: 214-28.

Fitzgerald, J.J. 1988. Irish journal of agricultural research 25: 327-45.

Gill, Margaret; Ulyatt. M.J. 1977. Journal of agricultural science (Cambridge) 89: 43-51.

Harris, AJ.; Hickey, M.J. 1978. Proceedmgs NZ Grass/and Association 40: 34-43

Hickey, M.J.; Baxter, G S 1989 Proceedings NZ Grassland Association 50:

Hughes. T.P. 1983 In Lamb Growth Technical Handbook 1983 Lincoln College.

Kennedy, P.M. 1983. Proceedings NZ Society of Animal Production 43. 123-25

MAFF 1978. Non-protein nitrogen for ruminants. ADAS LGR53

Orskov, E.R.; McDonald, I.; Grubb, R.A.; Pennie, K 1976. Journal of agricultural science (Cambridge) 66: 411 23

Ulyatt, M.J.: Fennessy, P.F., Rattray, P.V.; Jagusch, KT. 1980. In Supplementary feeding. NZ Society of Animal Productron Occasional Publication 7.

Wolton, KM., Brockman, J.S.; Shaw, P.C. 1970. Journal of the British Grass/and Society 25. 1 13-I 8. 